\title{
Morphometric and Ultrastructural Studies of the Effect of Infrared Laser on Rabbit Temporo-Mandibular Joint Fibroblasts
}

\author{
Ricardo Cornejo Uribe ${ }^{1 *}$, Fernando Matamala $\operatorname{Vargas}^{1}$, Héctor Silva Mella ${ }^{1}$ and Orlando \\ Garrido Onate ${ }^{2}$ \\ ${ }^{1}$ Departamento de Ciencias Básicas; Facultad de Medicina; Universidad de La Frontera; Temuco - Chile. ${ }^{2}$ Instituto \\ de Embriología; Universidad Austral de Chile; Valdivia - Chile
}

\begin{abstract}
The infrared laser beams has been successfully used in joint lesions treatment due to its analgesic anti inflamatory and healing action, and on a cellular level, inducing an accentuated synthesis of ATP, activating cellular proliferation and collagen synthesis. Samples of normal-control and irradiated tissue from temporo-mandibular joint disc of rabbit, were obtained, with daily doses of 2 joules $/ \mathrm{cm}^{2}$ during 10 consecutive days. They were prepared for transmission electronic microscopy.Transmission electronic micrographs of normal and irradiated fibroblasts were obtained with final increase of $11.500 \mathrm{X}$ for morphometric studies with the purpose of quantifying the volumetric fractions of the cellular components pertaining to the mentioned cellular types. Volumetric fractions of the quoted cell corresponding to nucleus, cytoplasm, rough endoplasmatic reticule, eu and heterochromatin were evaluated. In the same manner, the nucleus - cytoplasmatic relation and the area of each cellular type were quantified. The results derived from the morphometric comparative study between the normal and irradiated fibroblasts indicated that there were significant differences with respect to the volumetric fractions of euchromatin and heterochromatin and fundamentally in the cellular areas of both types. On the other hand, the rest of quantified parameters remained constant. It could be concluded that the cellular function reflected in collagen synthesis and secretion remained constant in both cellular types. However, by means of infrared laser stimulations, this fibroblast facilitated protein synthesis, due to high percentage of transcriptionally active euchromatine.
\end{abstract}

Key Words: Fibroblasts, Laser, Morphometry

\section{INTRODUCTION}

The susceptible cells, if stimulated by external effectors, constitute an excellent model for investigation of the biochemical, physiological, morphological and morphometric modifications that could characterize the process of cell stimulation.

In this context, the use of infrared laser treatment is useful in the temporo-mandibular joint treatment

*Author for correspondence: rcornejo@ufro.cl 
resulting an analgesic effect (Kim and Lee, 1992), healing and anti- inflammatory effect (O" Kanes et al., 1994; Lilge et al., 2000), inducing an accentuated synthesis of ATP, (Colls Cruñas, 1984; Karu, T. 1998), cellular proliferation (Porreau-Schneider et al., 1989), and variation in the metabolism of collagen (Pereira et al., 2002) on a cellular level.

In view of the above, it seemed important to study the morphological and morphometric differences observed between the temporo-mandibular joint disc fibroblasts pertaining to normal rabbits and those whose changes in their phenotype generated by a daily stimulation with infrared laser for a period of 10 consecutive days as the cause of modifications that would entail the alteration of its gene expression.

Considering that study of Cell Biology demonstrates that as long as the cells are stimulated, its components are subject to qualitative, quantitative and surface modifications, the analysis of electronic micrographs show how the modification of different components reflects into cellular function, pointing out the susceptible changes to be evaluated and compared between the normal and stimulated cells in relation to its morphological and morphometric aspects that determine the ultra-structural modifications pattern characterizing the radiation stimulation, in this biological model. (Junqueira and Salles, 1975).

\section{MATERIALS AND METHODS}

\section{Transmission Electronic Microscopy}

Starting with the discs pertaining to the temporomandibular joint of normal control rabbits and irradiated daily with infrared laser for a period of 10 consecutive days, samples were obtained for the investigation of fibroblasts. A solution of $2 \%$ glutaraldehyde in phosphate buffer $(0.15 \mathrm{M}, \mathrm{pH}$ 7.2) was added to these samples at room temperature for $2 \mathrm{~h}$. Subsequently, it was submitted to a wash solution of $6 \mathrm{~g}$ of $\mathrm{NaC} 1$ and $73 \mathrm{~g}$ of sucrose dissolved in 11 of distilled water. Post fixation took place in a solution of osmium tetroxide $(1 \%)$ dissolved in the washing solution for one hour at $40^{\circ} \mathrm{C}$ and uranile acetate $(0,59 \%)$ for $18 \mathrm{~h}$. After washing, the material was dehydrated in growing concentrations of acetone (30 to 100\%) and embedded in Araldita 6005. Ultra fine slices of approximately $70 \mathrm{~nm}$ of thickness, were obtained which were treated with $2 \%$ uranile acetate for 40 minutes and $0.5 \%$ lead citrate for 10 minutes.

The samples were studied and photographed in a Phillips EM 300 electronic microscope.

\section{Stereological Method}

Beginning with the blocks for electronic microscopy, ultra fine slices were obtained in which each one of the cellular types were micrographed with an augmentation of $11.500 \mathrm{X}$.

For the evaluation of volumetric fractions of the different cellular components, a reticule of points was placed above the electronic micrographs and a differential count of the points having an incidence over the profiles of the cellular components took place, calculating the volumetric fraction occupied by a given component with the following equation:

$$
F_{v}=\frac{P a}{P t}
$$

Where:

Fv: Volumetric fraction of the cellular component $\mathrm{Pa}$ : Points having an incidence over the component of the investigation

Pt: Total points having an incidence on the investigated cell

For the calculation of the cellular area, a Polar Ott Kempte, Bayern Germany

Planimeter was used.

\section{RESULTS}

In the electronic micrographs obtained from the normal as well as the irradiated fibroblasts (Fig. 1 and 2), the corresponding morphometric analysis were done, thus determining that the product of the stimulations of the infrared laser was cytologically reflected throughout the following parameters: 


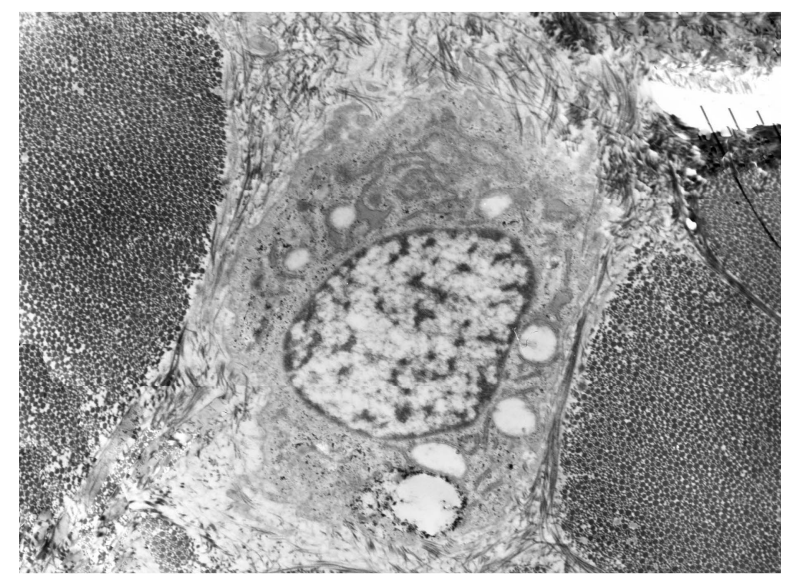

Figure 1 - Electronic micrograph of normal fibroblast pertaining to the disc of the temporomandibular joint of the rabbit $11.500 \mathrm{X}$.

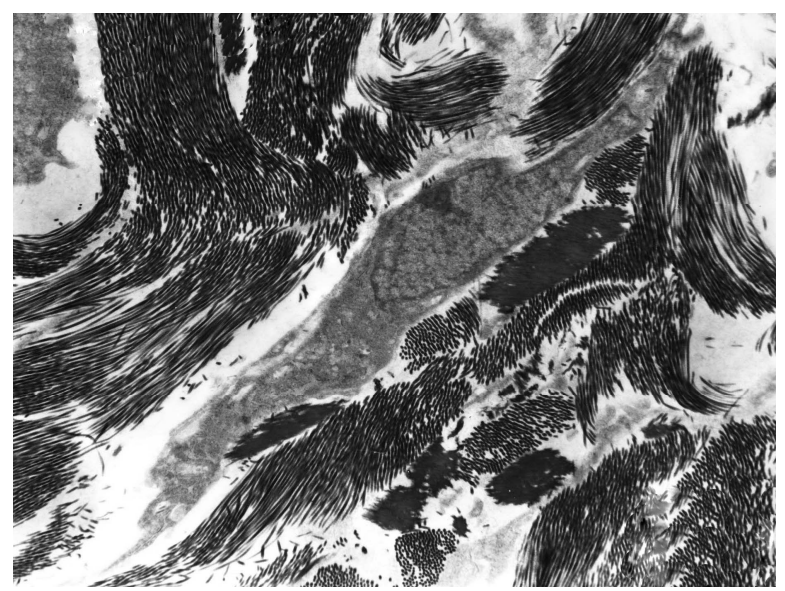

Figure 2 - Electronic micrograph of the irradiated fibroblast pertaining to the disc of the temporomandibular joint of the rabbit $11.500 \mathrm{X}$.

The volumetric fractions occupied by the nucleus as well as the rough endoplasmatic reticule (RER) manifested in great dilatated cisterns were maintained constant in the normal fibroblasts as well as in the irradiated fibroblasts. Results are in Figure 3.

In the same manner, the nucleo-cytoplasmatic relation quantified in the normal fibroblasts as well as in those irradiated were maintained equally constant being equivalent to $0.4 \%$.
The volumetric fractions corresponding to the euchromatine increased, while those corresponding to the heterochromatin decreased from the normal fibroblasts to those irradiated (Fig. 4)

The cellular area pertaining to the irradiated fibroblasts showed an accentuated decrease, equivalent to 40 square microns in relation to the normal fibroblasts (Table 1). 


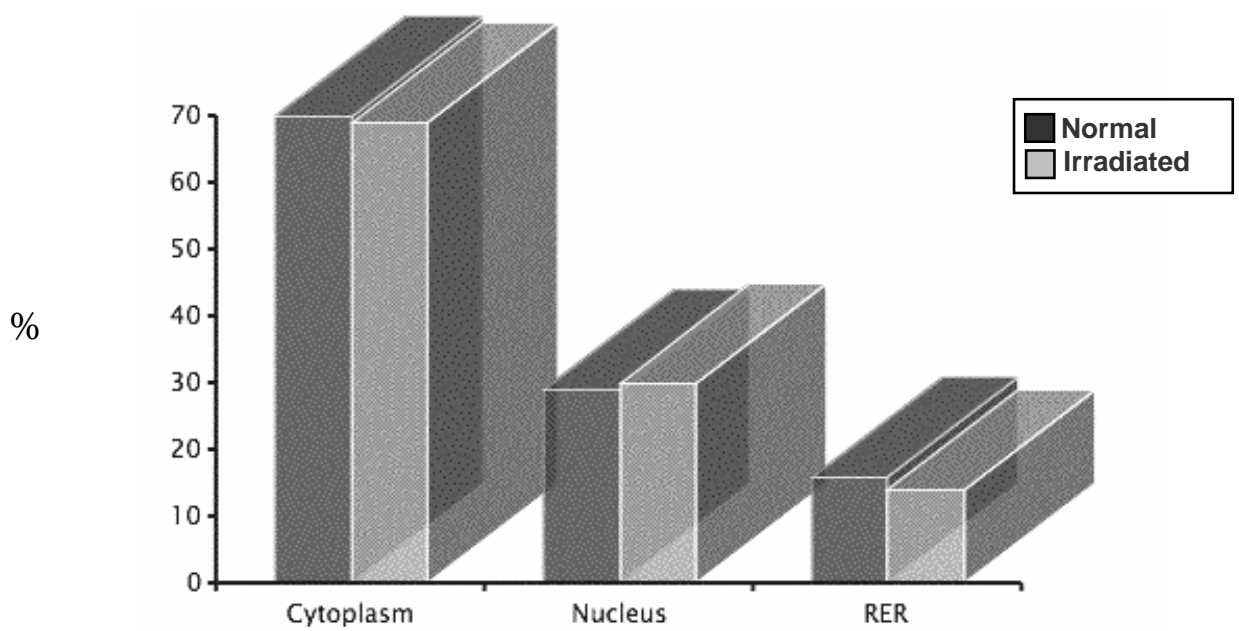

Figure 3 - Volumetric fractions $(\%)$ corresponding to the components of normal and irradiated fibroblasts pertaining to the disc of the temporo-mandibular joint of the rabbit.

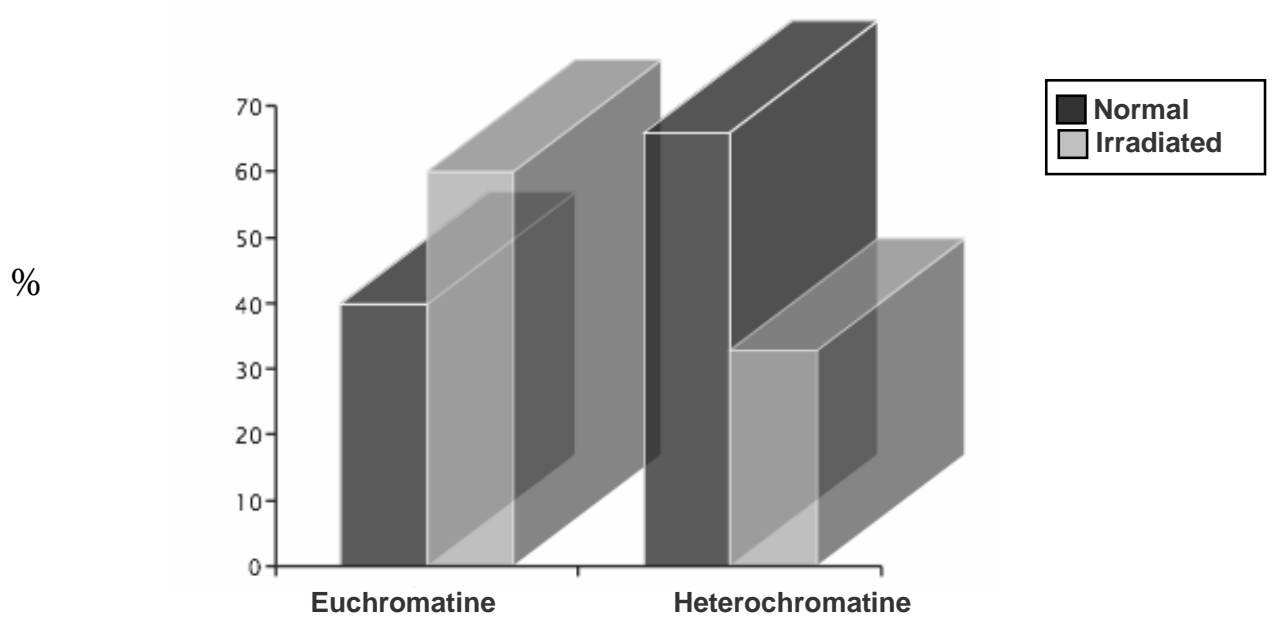

Figure 4 - Volumetric fractions of chromatine evaluated in normal and irradiated fibroblasts pertaining to the temporo-mandibular joint of the rabbit.

Table 1 - Cellular area $\left(\mathrm{u}^{2}\right)$ corresponding to normal and irradiated fibroblasts pertaining to the disc of the temporomandibular joint of the rabbit.

\begin{tabular}{ll}
\hline Cell Type & Cellular Area \\
\hline Normal Fibroblast & 82 square microns \\
Irradiated Fibroblast & 40 square microns \\
\hline
\end{tabular}

\section{DISCUSSION}

The results from the analysis of the morphological data obtained with the transmission electronic microscopy fundamentally considering those relative to the similar volumetric fractions of cytoplasm, nucleus and those corresponding to the rough endoplasm reticule from the normal as well as irradiated fibroblasts, demonstrated that these cells possessed similar morphological parameters, 
indicating that the effects produced by the stimulations with infrared laser did not have an inhibiting action, nor an activating one of the cellular activity, situation which would translate in concluding primarily that these cells displayed a cellular function translated to a rate of protein synthesis-secretion practically similar.

These data differed from those described by Marques et al. (2004), which found that the effect of laser generated ultrastructural changes in human gingival fibroblasts, which would cause abnormality in the collagen synthesis.

The present results differed from those obtained by Chomette et al. (1987) working which human gingival fibroblasts, who found that the stimulations with laser produced an accentuated increase in the development of rough endoplasmic reticulum, an increase in the number of mitochondria and cytoplasmatic granular material, translated to an increase of metabolic activity.

In relation to the absence of intracellular collagen, the present results coincided with those of Berkovitz and Pacy (1999) obtained by studying the ultra structure of the fibro-cartilage also pertaining to the temporo-mandibular joint of the rabbit.

The present findings also coincided with those found by Pogrel et al. (1997) in the sense that cultured fibroblasts stimulated by laser did not cause changes in the characteristic activity of the fibroblast such as migration, proliferation and cellular adhesion.

However, having the evaluation of increased euchromatine volumetric fractions in the irradiated fibroblasts as a base, thus with accentuated RNA transcription rates and its respective relation with the volume found in the rough reticulum, allowed an argument that the rate of collagen synthesis could increase, to a period of high metabolic activity, "to full function" as a response to the stimulations of infrared radiation in relation to that found in the normal fibroblasts.

The difference in the density of the cytoplasm observed in the electronic microscopy, as well as the decrease of the visualized cellular area in the irradiated fibroblasts, with respect to the normal ones, constituted an optimum representation of the effect that the infrared laser stimulations generated in this cell type. It would be pertinent to recall that this effect, a product of the radiation, decreased the area of the irradiated cell to one half, (82 to 40 square microns) transforming it in the typical morphology of a "juvenile" fibroblast, making it tempting to suppose that this situation was the translation of a change in the gene expression modulated by these infrared stimulations.

\section{RESUMO}

$\mathrm{O}$ raio laser infravermelho tem sido usado com sucesso no tratamento de lesoes articulares por sua ação analgesica, antinflamatoria e cicatrizante e, ao nivel celular, induzindo acentuada síntese de ATP, ativando a proliferação celular e a síntese do colágeno.

Foram obtidas amostras do disco da articulação temporo-mandibular de coelhos que foram irradiados com raio laser e de outras não irradiadas que foram consideradas como controle normal. As doses diarias de irradiação foram de 2 Joules $/ \mathrm{cm}^{2}$ durante 10 dias. As amostras foram tratadas para microscopia eletrônica de transmissão.

Dos fibroblastos normais e irradiados obtiveram-se microfotografias eletrônicas de transmissão com aumentos finais de $11.500 \mathrm{X}$, realizando-se estudos morfometricos com propósito de quantificar as frações volumétricas dos componentes celulares pertencentes aos tipos celulares assinalados.

Das células indicadas avaliaram-se frações volumétricas correspondentes ao núcleo, citoplasma, retículo endoplásmico rugoso, eucromatina e heterocromatina. Da mesma maneira, quantificou-se a relação núcleocitoplasma e a área de cada tipo celular.

Os resultados originados do estudo morfométrico comparativo entre fibroblastos normais e irradiados, indicaram que existem diferencas significativas nas frações volumétricas de eucromatina e heterocromatina e fundamentalmente nas áreas celulares de ambos os tipos. Os outros parâmetros quantificados mantiveram-se constantes. A conclusão é que a função celular traduzida em síntese e secreção de colágeno é constante em ambos os tipos celulares, contudo, produto das estimulações com raio laser infravermelho este fibroblasto tem tendência devido a sua percentagem de eucromatina transcripcionalmente ativa a uma sintese imediata e facilitada de proteinas. 


\section{REFERENCES}

Berkovitz, B. K; Pacy, J. (1999), The ultrastructure of an intra-articular disc of the temporo-mandibular joint, with special reference to fibrocartilage. Bull Group Int Rech Sci Stomatol Odontol 4 (1), 2-13.

Chomete, G, Auriol, M; Zeitoun, R; Mousques, T. (1987), Effect of the soft laser on gingival connective tissue. Effect on fibroblasts. Histoenzymology and electron microscopy study. J Biol Buccale 15(1),4549.

Colls Cruñas, J. (1984), La terapia láser hoy. Barcelona: Centro de Documentación Láser, 112-37.

Junqueira, L. C. U.; Salles, LMM.(1975), Ultraestrutura e funçao celular. Rio de Janeiro, GuanabaraKoogan, 121p.

Karu, T. (1998), The Science of Low Power Laser Therapy. Gordon and Breach, London .

Kim, K. S; Lee, DHK.(1992), Effects of Leww incident evergy-levels of infrared laser irradiation on the proliferation of Streptococus mutans. Laser Ther. 4,81-85.

Lilge, L; Tierney, K; Nussbaum E.(2000), Low-level laser therapy for wound healing: Feasibility of wound dressing transillumination. J Clin Laser Med Surg. 18 (5), 235-240.
Marques, M. M; Pereira, AN; Fujihara,NA Nogueira, F. N; Eduardo, C. D. P. (2004), Effect of low-power laser irradiation on protein synthesis and ultrastructure of human gingival fibroblasts. Laser in Surgery and Medicine 34, 260-265.

O'Kanes, C. G. A., Hannigav, BM; Gil More, W. S.; Allen, J. M. (1994), Low intensity casu irradiation induces cytokine release from two haemopoietic cell lines. Laser Sing Med. 6, 8-10.

Pereira, A. N, Eduardo, C. P; Matson, E; Marques, M. M.(2002), Effect of low power laser irradiation on cell growth and procollagen synthesis of cultured fibroblasts. Lasers Surg Med. 31 (4), 263-267.

Pogrel, MA; Chen, J.W., Zhang, K. (1997), Effects of low energy gallium aluminum arsenide laser irradiation on cultured fibroblasts and keratinocytes. Lasers Surg Med. 20 (4), 426-432.

Pourreau-Schneider N; Soudry, M; Remusat, M; Franquin, J. C.; Martin, PM. (1989), Modification of growth dynamic and ultrastructure after helium-neon laser treatment of human gingival fibroblasts. Quintessence Int, 20, 887-893.

Received: April 10, 2007 Revised: September 17, 2007; Accepted: May 23, 2008. 